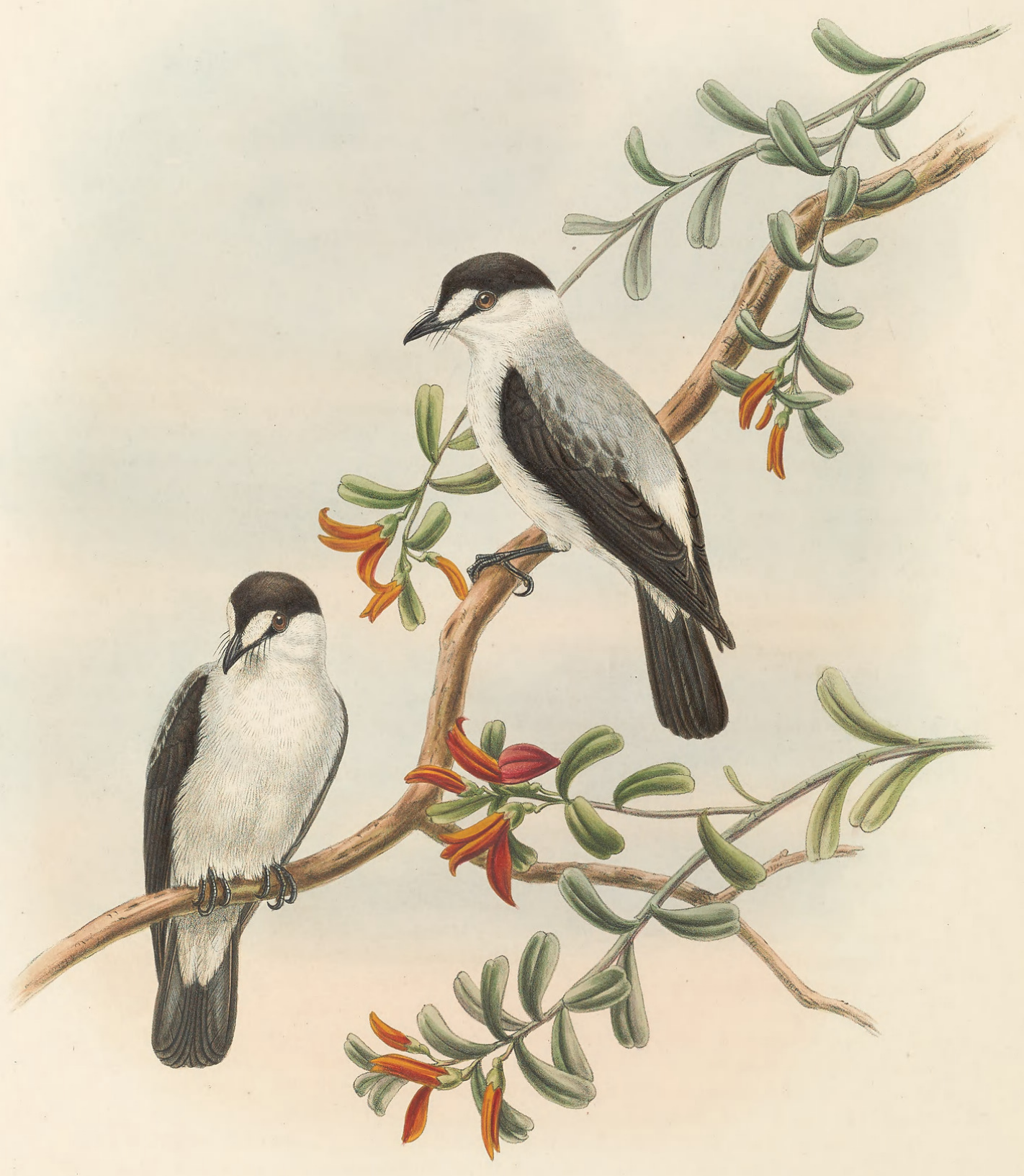




\title{
MONACHELLA MUELLERIANA.
}

\author{
Chat-like Flycatcher.
}

\begin{abstract}
Muscicapa mulleriana, Schlegel (nec Muscicapa mulleri, Temm.), Ned. Tijdschr. Dierk. iv. p. 40 (1871).
Monachella saxicolina, Salvad. Ann. Mus. Civ. Gen. vi. p. 63 (1874).-Beccari, ibid. vii. p. 709 (1875).D’Albertis, Sydney Mail, 1877, p. 248.-Id. Ann. Mus. Civ. Gen. x. p. 11 (1877).-Salvad. op. cit. x. p. 11 (note), p. 133 (1877)._D'Alb. \& Salvad. op. cit. xiv. p. 59 (1879)._Salvad. op. cit. p. 501 (1879).Id. Orn. Papuasia \&c. p. 83 (1881.)

Monachella mulleriana, Salvad. Ann. Mus. Civ. Gen. vi. p. 308 (1874, note).-Sharpe, Cat. B. Brit. Mus. iv. p. 240 (1879).

Micrœeca albofrontata, Ramsay, Proc. Linn. Soc. New S. Wales, iii. p. 304 (1879), iv. pp. 90, 98 (1879)—Salvad. Ibis, 1859 , p. 323.
\end{abstract}

I AM sorry that I cannot follow my friend Count Salvadori in calling this bird Monachella saxicolina (although his reasons are worthy of some consideration), as he has only preferred to use that name to avoid the confusion that might take place between Muscicapa muelleriana of Schlegel and Muscicapa muelleri of Temminck. I do not think, however, that there is really much chance of this confusion, as the latter bird is a Flycatcher belonging to the genus Erythromyias, and is an inhabitant of Sumatra and Borneo. Professor Schlegel's name having been published three years before that of Count Salvadori, it has an undoubted claim to priority. In other respects the name of saxicolina is extremely well chosen, as indicating the habits of the bird; and Signor D'Albertis states that when he first saw the species on the torrents of the Arfak Mountains he really thought that it was a true Saxicola.

Dr. Beccari also says that in the above-named locality he found the species abundant, but only in the streams near the sea. During his expedition up the Fly river, D'Albertis met with the species along the banks, and relates how, when the water was low, it perched on small rocks at the side of the river, and was continually in motion flying after insects. Mr. Goldie also states that during his recent expedition to the Astrolabe Mountains he found the species, in company with Grallina bruijnii, flying about creeks and hopping amongst the stones.

As far as we know, the present bird is exclusively confined to New Guinea. A specimen was procured by Solomon Müller in Lobo Bay as long ago as 1828, though it does not seem to have been described till 1871 . It also inhabits the Arfak Mountains, and has been met with at Karons by M. Laglaize. In the southern part of the island D'Albertis met with it on the Fly river; and Mr. Goldie procured it on the Goldie river inland from Port Moresby. He has more recently met with it in the Morocco district, at the back of the Astrolabe range of mountains in South-eastern New Guinea : here it is called Iada.

The following description is taken from Mr. Sharpe's 'Catalogue of Birds : '

“Adult male. General colour above light French grey, paler on the lower back, the rump and upper tailcoverts white; wings and tail dark brown; crown of head and nape dark brown, as also the feathers above the eye and the upper edge of the eyelid, the brown narrowing on the forehead to the base of the bill; lores and feathers over the front of the eye pure white; between the eye and the base of the bill a triangular patch of blackish feathers; sides of face and ear-coverts, as well as entire under surface of body, creamy white; under wing-coverts dark brown; 'bill and feet black' (D'Albertis). Total length $5 \cdot 5$ inches, culmen $0 \cdot 6$, wing $3 \cdot 8$, tail $2 \cdot 4$, tarsus $0 \cdot 65$.

"Adult female. Similar to the male. Total length $5 \cdot 3$ inches, culmen $0 \cdot 6$, wing $3 \cdot 55$, tail $2 \cdot 25$, tarsus $0 \cdot 65$."

Count Salvadori says that the young bird has the head and the wing-coverts blackish brown spotted with white, the back dull whitish varied with dusky, and the tips of the tail-feathers white.

The figures in the Plate represent a pair of birds of the size of life, and are drawn from a specimen collected by $\mathrm{Mr}$ Goldie, and now in the British Museum. 


\section{$2 \mathrm{BHL}$ Biodiversity Heritage Library}

Gould, John and Sharpe, Richard Bowdler. 1882. "Monachella muelleriana, Chat-like Flycatcher [PI. 16]." The birds of New Guinea and the adjacent Papuan islands : including many new species recently discovered in Australia 2(XIII), -. https://doi.org/10.5962/p.322671.

View This Item Online: https://www.biodiversitylibrary.org/item/229877

DOI: https://doi.org/10.5962/p.322671

Permalink: https://www.biodiversitylibrary.org/partpdf/322671

\section{Holding Institution}

Smithsonian Libraries

\section{Sponsored by}

Biodiversity Heritage Library

\section{Copyright \& Reuse}

Copyright Status: Public domain. The BHL considers that this work is no longer under copyright protection.

This document was created from content at the Biodiversity Heritage Library, the world's largest open access digital library for biodiversity literature and archives. Visit BHL at https://www.biodiversitylibrary.org. 